\title{
Nutritional Fortification of Sunflower Meal by Bacillus Subtilis ATCC PTA-6737 Fermentation
}

\author{
Sulhattin YASAR ${ }^{1 *}$, Caner UYSAL ${ }^{2}$, Ramazan TOSUN ${ }^{1}$ \\ ${ }^{1}$ Department of Animal Science, Faculty of Agriculture, Igdir University, Şehid Bülent Yurtseven \\ Yerleşkesi, Suveren Igdir, 76000Turkey. \\ ${ }^{2}$ Department of Animal Science, Faculty of Agriculture, Suleyman Demirel University, Isparta, 32660, \\ Turkey \\ *corresponding author: sulhattin.yasar@gmail.com
}

Bulletin UASVM Animal Science and Biotechnologies 75(2)/ 2018

Print ISSN 1843-5262; Electronic ISSN 1843-536X

DOI:10.15835/buasvmcn-asb: 2018.0008

\begin{abstract}
Sunflower meal with $3 \mathrm{~mm}$ particle size (SFM) with 66 or $80 \%$ moisture content was inoculated with $1 \times 10^{7}$ cfu (colony forming unit/g) of Bacillus subtilis ATCC PTA-6737 and fermented for 0, 24, 48 and $72 \mathrm{~h}$. The pH was increased from 5.75 to 9.1 of SFM fermented at both moisture levels with no significant changes in organic acid production. The bacterial growth was peaked at $24 \mathrm{~h}$. Dry matter and crude fibre contents of SFM decreased by 10-13 and $18 \%$, respectively. In contrary, the amount of crude protein, crude ash and soluble amino acid nitrogen increased by $36,61 \%$ and $145 \%$, respectively, with no regard to the effect of moisture content. Phytic acid was degraded up to $42 \%$ at both level of moisture content. In conclusion, SFM was enriched with ash and protein and lowered in fibre and phytic acid contents, and can be used as alternative feed material in animal nutrition.
\end{abstract}

Keywords: Bacillus subtilis, sunflower meal, fermentation, nutrient fortification

\section{INTRODUCTION}

Sunflower meal (SFM) has been used in animal nutrition as a second plant protein source after soybean meal (SBM), but its use is limited due to its high fibre content and some antinutrional factors (ANFs), especially for feeding some poultry species (Sangsoponjit et al., 2017).Solid state fermentation (SSF) using safe microorganisms is a process of fermentation where solid materials are immersed in water, and the production yield of several products such as enzymes, organic acids, aromatic and antimicrobial agents is greater than liquid state fermentation process (Raimbault, 1998; Singhaniaa et al., 2009; Afşin, 2010; Özşölen, 2010; Ravichandran and Vimala, 2012 and Mukherjee et al., 2016). For instance, SFM can be used as fermenting substrate in microbial fermentation process to produce protease (Haq and Mukhtar, 2004) and lipase enzymes (Karakoç, 2006). Bacillus subtilis is a gram-positive bacteria, found in soil and gastrointestinal tract (Yonsel, 2010) and widely used in many industrial applications (Yonsel, 2010; Constantinscu and Petruta, 2015). Moreover, several species of Bacillus have been used to produce amylase (Baysal et al., 2002; Choubane et al., 2015) and alkaline protease enzyme (Uyar and Baysal, 2004; Patel et al., 2005; Prakasham et al., 2007; Mukherjee et al., 2008).

Enzymatic hydrolysis or defatting process of SFM was earlier shown to increase the crude protein levels (Cai et al., 1996). Recently, microbial fermentation of feed materials including SFM with Saccharomyces cerevisiae or Bacillus subtilis has been shown to increase the contents of crude protein, lipid and some essential amino acid; all these were associated with reduced crude fibre content and degradation of ANFs such as chlorogenic acid, caffeic acid, phytic acid and saponins (Azza et al., 2013; Hassaan et al., 2018). In particular, Bacillus subtilis has been successfully used in SSF process to improve bio-availability of feed nutrients (Kiers et al., 2003), to produce 
biologically functional products used as enzyme and probiotics enriched immune regulators and performance promoters (Kumar and Duhan, 2011 and Yamamoto et al., 2007), or to obtain new alternative feeding materials which were reduced in ANF and fibre contents (Nair, 1990; Pal vig and Walia, 2001 and Barnes et al., 2012; Safari et al., 2012; Nutraferma, 2014 and Zhang et al., 2014).

The strain of Bacillus subtilis ATCC PTA-6737 is a safe microorganism, and has been widely used in solid state fermentation processes for the production of feed additives, mainly probiotics and enzymes and enrichment of feed materials (Nutraferma, 2014 and Zhang et al., 2014). Optimum conditions for the cultivation of Bacillus subtilis ATCC PTA-6737 were $37{ }^{\circ} \mathrm{C}$ of temperature and 7.0 of $\mathrm{pH}$ under aerobic condition for $12 \mathrm{~h}$ using fermentation nutrient broth according to the culture collection centres of ATCC of the global bioresource centre and DSMZ (Deutsche Sammlung von Mikroorganismen und Zellkulturen). These conditions were optimised for its application in SSF processes, usually ranging from a $30-37{ }^{\circ} \mathrm{C}$ of temperature, $6.5-7.0$ of $\mathrm{pH}, 40$ to $80 \%$ of moisture content of fermenting substrate, 20 to $150 \mathrm{rpm}$ (round per min) of stirring, under aerobic condition of 0.25 to $0.75 \mathrm{~L} / \mathrm{min}$ of aeration rate for 24 to $72 \mathrm{~h}$ using plant feed materials such as soybean meal, soybean, corn, cereal grains and some other agro-wastes such as fruit pomaces its application in SSF (Gessese and Mamo 1999; Joseph et al., 2008; Chantet et al., 2011; Azza et al., 2013; Zhang et al., 2014; Shi et al., 2017).

Fermented SFM with nutritionally improved qualities could be an alternative feeding material in monogastric animal nutrition as opposed to their use in ruminants. A recent study showed that fermentation of SFM for the purpose of pig and poultry nutrition resulted in improved nutrient content (particularly increased protein and degraded crude fiber) and reduced dietary ANFs (Poulsen and Blaabjerg 2017). Nutritionally enriched SFM fermented with yeast and Bacillus subtilis in SSF process was even successfully incorporated up to $25 \%$ into a compound fish diet (Soltan et al., 2015; Hassaan et al., 2018). Moreover, the diets of shrimps could be added up to a $5 \%$ inclusion of fermented SFM with fungal microorganism (Jannathulla et al., 2018).

All the above research studies indicated that SSF using safe microorganisms could lead to successful enrichment treatment of SFM which could have a high potential for feeding of monogastric animals. Moreover, SSF using bacteria inoculant such as Bacillus subtilis could be of significant importance to produce nutritionally enriched feed material. To our best knowledge, the effect of Bacillus subtilis fermentation under optimum fermentation condition on the nutritional composition of SFM has been rarely investigated.

Therefore, this study was conducted to ferment SFM with two moisture contents (66 and $80 \%, \mathrm{w} / \mathrm{w}$ ) by Bacillus subtilis ATCC PTA-6737 fermentation for nutritional enrichment.

\section{MATERIALS AND METHODS}

Bacillus subtilis ATCC PTA-6737 purchased from ATCC (LGC Standards GmbH Mercatorstr. 51 46485 Wesel Germany) in the form of lyophilised pellet was cultivated on Brain Heart Infusion Broth at $37{ }^{\circ} \mathrm{C}$ for $24 \mathrm{~h}$ to collect sufficiently enough inoculant for fermentation. The cultivated bacteria were immersed in saline solution used as inoculant and its bacteria count determined as cfu (colony forming unit) /g wet mass $(\mathrm{w} / \mathrm{w}$ ) by the method reported by ISO (2004) at $37^{\circ} \mathrm{C}$ for $24 \mathrm{~h}$. SFM sample was bought from a local feed mill and ground to pass a 3-mm sieve. Autoclaved sample of SFM in glass flasks at $121^{\circ} \mathrm{C}$ for 60 min was added with sterilised distilled water to obtain a sample with 66 or $80 \%$ moisture content $(\mathrm{w} / \mathrm{w})$, followed by inoculation of bacteria at a rate of $1 \times 10^{7} \mathrm{cfu}$ per g solid material, and left for fermentation at $37{ }^{\circ} \mathrm{C}, \mathrm{pH}=7.0$, aeration rate of $0.75 \mathrm{~L} / \mathrm{min}$ with a constant stirring of $150 \mathrm{rpm}$ for $0,24,48$ and $72 \mathrm{~h}$ using an orbital benchtop shaker (Thermo Scientific Inc.) with the control of fermentation parameters. These fermentation condition for SSF of SFM were carefully selected from the literature (Gessese and Mamo 1999; Joseph et al., 2008; Chantet et al., 2011; Azza et al., 2013; Zhang et al., 2014; Shi et al., 2017). The experimental design was of 2 moisture levels ( 66 and $80 \%, w / w$ ) x 3 replicates $x 4$ incubation periods $(0,24,48$ and 72 $\mathrm{h})$. At the end of each incubation period, bacteria count (ISO 2004) and pH values of fermenting substrate were immediately measured. And then wet samples were dried at $50{ }^{\circ} \mathrm{C}$ until a constant weight of sample was obtained. The crude protein, crude fibre and crude ash were determined by the methods of AOAC (1990). The content of soluble nitrogen and organic acids (mainly 
Table 1. Changes in $\mathrm{pH}$, bacteria count (cfu/g of dried sample) and organic acids (\% of dried sample) of fermented SFM

\begin{tabular}{|c|c|c|c|c|c|}
\hline Time (h) & $\mathrm{pH}$ & $\begin{array}{c}\text { Bacteria count cfu/g of } \\
\text { dried sample }\end{array}$ & Acetic acid \% & Butyric acid \% & Lactic acid \% \\
\hline \multicolumn{6}{|c|}{$66 \%$ moisture content $(\mathrm{w} / \mathrm{w})$} \\
\hline 0 & $5.73 \pm 0.11^{\mathrm{a}}$ & $3.3 \times 10^{6} \pm 0.05^{\mathrm{a}}$ & $2.20 \pm 0.33^{\mathrm{a}}$ & $1.15 \pm 0.05^{\mathrm{a}}$ & $0.95 \pm 0.05^{\mathrm{a}}$ \\
\hline 24 & $7.67 \pm 0.15^{b}$ & $2.8 \times 10^{9} \pm 0.03^{\mathrm{b}}$ & $4.74 \pm 1.73^{b}$ & $0.00 \pm 0.00^{\mathrm{b}}$ & $5.5 \pm 1.42^{\mathrm{b}}$ \\
\hline 48 & $9.1 \pm 0.13^{\mathrm{c}}$ & $4.1 \times 10^{9} \pm 0.015^{c}$ & $1.08 \pm 0.022^{c}$ & $0.54 \pm 0.30^{c}$ & $3.18 \pm 1.29^{b}$ \\
\hline 72 & $8.67 \pm 0.17^{c}$ & $5.9 \times 10^{9} \pm 0.010^{\mathrm{d}}$ & $1.47 \pm 0.42^{\mathrm{c}}$ & $0.06 \pm 0.03^{b}$ & $1.09 \pm 0.14^{\mathrm{c}}$ \\
\hline \multicolumn{6}{|c|}{ 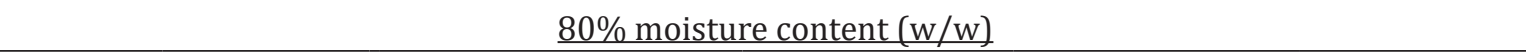 } \\
\hline 0 & $5.84 \pm 0.10^{\mathrm{a}}$ & $3.6 \times 10^{6} \pm 0.02^{\mathrm{a}}$ & $2.0 \pm 0.3^{\mathrm{a}}$ & $1.15 \pm 0.05^{\mathrm{a}}$ & $0.95 \pm 0.05^{\mathrm{a}}$ \\
\hline 24 & $7.50 \pm 0.12^{\mathrm{b}}$ & $2.2 \times 10^{9} \pm 0.01^{\mathrm{b}}$ & $2.19 \pm 0.006^{\mathrm{a}}$ & $0.00 \pm 0.00^{\mathrm{b}}$ & $1.24 \pm 0.011^{\mathrm{b}}$ \\
\hline 48 & $8.07 \pm 0.14^{\mathrm{c}}$ & $7.3 \times 10^{9} \pm 0.015^{c}$ & $2.04 \pm 0.12^{\mathrm{a}}$ & $0.00 \pm 0.00^{\mathrm{b}}$ & $1.18 \pm 0.20^{\mathrm{b}}$ \\
\hline 72 & $7.15 \pm 0.18^{\mathrm{b}}$ & $9.5 \times 10^{9} \pm 0.60^{\mathrm{e}}$ & $4.35 \pm 0.001^{\mathrm{b}}$ & $0.07 \pm 0.005^{b}$ & $1.70 \pm 0.03^{c}$ \\
\hline
\end{tabular}

Note: Different letters in the same column indicated significant (Duncan test, $P<0.05$ ) differences between the means \pm standard deviation.

acetate, lactate and butyrate) were determined by the methods reported by Karabulut and Canbolat (2005). Phytate content was determined spectrophotometrically by the method of Raheja et al. (1973). Protease activity (IU/g) was determined as ability to hydrolysis $0.8 \%(\mathrm{w} / \mathrm{v})$ azocasein protein by the method of Cotta et al. (1986). For all microbiological and chemical analysis, $9(3 \times 3)$ measurements were performed per treatment (3 times of analysis of each of 3 samples (flasks) taken at the end of each fermentation period). The results of cfu and nutrients were expressed on the basis of dry matter of samples. .

A general linear model (GLM) was used to test the effect of water levels on the studied parameters using SPSS statistical program (IBM SPPS Inc, version 23), where the differences between the means of treatments were separated by Duncan' Multiple Comparison Test at a 0.05 significance level.

\section{RESULTS AND DISCUSSIONS}

The $\mathrm{pH}$ of SFM was significantly $(P<0.05)$ influenced by the incubation time, but not by the water content of SFM (Tab. 1). Increasing the incubation time induced significant $(P<0.05)$ increases in the $\mathrm{pH}$ from 5.73 at $0 \mathrm{~h}$ to 9.1 at $48 \mathrm{~h}$ of fermentation. As overall, the production of total organic acid did not greatly change during the fermentation of SFM between the SFM samples with 66 or $80 \%$ moisture contents (w/w), but there were sporadic changes in acetic and lactic acids over the fermentation period. Similarly, significant $(P<0.05)$ increases in bacterial growth were observed with fermentation of SFM with both moisture levels. The changes in fermentation parameters in this study indicated successfully optimized fermentation. The range of $\mathrm{pH}$ values in our study was similar to earlier results reported by Sneath (1986), and the raised $\mathrm{pH}$ values in our study was found as a result of the production of alkaline protease by Bacillus subtilis (Sarkar et al., 1993 and Chantawannakul et al., 2002). If the desired aim is to produce more alkaline protease enzyme in SSF process we recommend that the fermentation period must be extended over a period of $72 \mathrm{~h}$, similar to the our study. SFM was reported to be a good substrate of producing alkaline protease in SSF studies (Haq and Mukhtar, 2004). Alkaline protease production in our study (Tab. 2) was significantly increased $(\mathrm{P}<0.05)$, which was also associated with increased amount of soluble amino acid nitrogen in our study, and the effect of moisture content of SFM on these parameters was insignificant. Similar increases in soluble amino acid nitrogen were reported by Kiers et al. (2000). It was earlier shown that the production of alkaline protease can be stimulated at high $\mathrm{pH}$ condition above 6.0 with constant stirring (Abusham et al., 2009), similar to the conditions set up in our study. The sporadic changes in individual organic acids seen in study 
Table 2. Effect of fermenting SFM at two levels of moisture content on nutritional composition (analysed nutrients were expressed as \% of dried sample)

\begin{tabular}{|c|c|c|c|c|c|}
\hline Parameters \% & $\begin{array}{c}\text { Moisture \% } \\
(\mathrm{w} / \mathrm{w})\end{array}$ & $0 \mathrm{~h}$ & $24 \mathrm{~h}$ & $48 \mathrm{~h}$ & $72 \mathrm{~h}$ \\
\hline \multirow{2}{*}{ Dry matter \% } & 66 & $34.0 \pm 0.05^{\mathrm{aA}}$ & $30.11 \pm 0.44^{\mathrm{bA}}$ & $28.18 \pm 0.19^{\mathrm{cA}}$ & $29.4 \pm 0.33^{\mathrm{cA}}$ \\
\hline & 80 & $20.0 \pm 0.01^{\mathrm{aB}}$ & $19.07 \pm 0.07^{\text {bB }}$ & $18.15 \pm 0.04^{\mathrm{cB}}$ & $18.4 \pm 0.29^{\text {св }}$ \\
\hline \multirow{2}{*}{ Crude ash \% } & 66 & $6.55 \pm 0.08^{\mathrm{aA}}$ & $7.14 \pm 0.13^{\mathrm{bA}}$ & $9.77 \pm 0.18^{\mathrm{cA}}$ & $10.0 \pm 0.14^{\mathrm{cA}}$ \\
\hline & 80 & $6.55 \pm 0.08^{\mathrm{aA}}$ & $9.47 \pm 0.18^{\mathrm{bB}}$ & $11.88 \pm 0.19^{\mathrm{св}}$ & $9.14 \pm 0.23^{\mathrm{bB}}$ \\
\hline \multirow{2}{*}{ Crude protein $\%$} & 66 & $35.25 \pm 0.014^{\mathrm{aA}}$ & $35.11 \pm 0.30^{\mathrm{aA}}$ & $47.06 \pm 0.18^{\mathrm{bB}}$ & $47.87 \pm 0.47^{\mathrm{bA}}$ \\
\hline & 80 & $36.35 \pm 0.10^{\mathrm{aA}}$ & $47.25 \pm 0.77^{\mathrm{bB}}$ & $45.97 \pm 0.18^{\mathrm{bB}}$ & $43.95 \pm 0.76^{\mathrm{cB}}$ \\
\hline \multirow{2}{*}{ Crude fibre \% } & 66 & $39,21 \pm 0,2^{\mathrm{aA}}$ & $36,66 \pm 1,14^{\mathrm{bA}}$ & $32,79 \pm 0,74^{\mathrm{aA}}$ & $36,99 \pm 0,03^{\mathrm{bA}}$ \\
\hline & 80 & $39,61 \pm 0,22^{\mathrm{aA}}$ & $37,07 \pm 1,37^{\mathrm{bA}}$ & $35,32 \pm 0,79^{\mathrm{bB}}$ & $34,68 \pm 0,55^{\mathrm{bB}}$ \\
\hline \multirow{2}{*}{ SAN \% } & 66 & $4.8 \pm 0.44^{\mathrm{aA}}$ & $11.44 \pm 0.25^{\mathrm{bB}}$ & $9.34 \pm 0.03^{\mathrm{cA}}$ & $10.29 \pm 0.03^{\mathrm{dA}}$ \\
\hline & 80 & $4.8 \pm 0.44^{\mathrm{aA}}$ & $11.80 \pm 0.18^{\mathrm{bB}}$ & $11.88 \pm 0.03^{\mathrm{bB}}$ & $11.70 \pm 0.65^{\mathrm{bA}}$ \\
\hline \multirow{2}{*}{$\begin{array}{c}\text { Protease Activity } \\
\text { IU/g }\end{array}$} & 66 & $2.5 \pm 0.4^{\mathrm{aA}}$ & $6.70 \pm 0.05^{\mathrm{aA}}$ & $6.75 \pm 0.01^{\mathrm{aA}}$ & $7.55 \pm 0.01^{\mathrm{bA}}$ \\
\hline & 80 & $2.5 \pm 0.4^{\mathrm{aA}}$ & $7.31 \pm 0.2^{\mathrm{bA}}$ & $7.40 \pm 0.3^{\mathrm{cB}}$ & $8.70 \pm 0.4^{\mathrm{dA}}$ \\
\hline \multirow[t]{2}{*}{ Phytic acid \% } & 66 & $0.40 \pm 0.02^{\mathrm{aA}}$ & $0.29 \pm 0.001^{\mathrm{bA}}$ & $0.23 \pm 0.05^{\mathrm{bA}}$ & $0.23 \pm 0.04^{\mathrm{bA}}$ \\
\hline & 80 & $0.40 \pm 0.02^{\mathrm{aA}}$ & $0.26 \pm 0.02^{\mathrm{bA}}$ & $0.27 \pm 0.01^{\mathrm{bA}}$ & $0.25 \pm 0.01^{\mathrm{bA}}$ \\
\hline
\end{tabular}

Note: Different letters in the same column indicated significant (Duncan test $P<0.05$ ) differences between the means \pm standard deviation. Different letters in the same row indicated significant (Duncan test $P<0.05$ ) differences between the means \pm standard deviation.

were found contradictory to the results of Ohara and Yahata (1996) obtained from the fermentation of many species of Bacillus at anaerobic conditions.

Fermentation SFM caused a significant reduction in dry matter contents of SFM with both moisture levels $(P<0.05)$, while the effect of $80 \%$ water level was more pronounced (Tab. $2)$. In addition, there were significant increases $(P<0.05)$ in crude ash contents of SFM with both levels of moisture. There were also significant increases $(P<0.05)$ in crude protein contents of SFM with both levels of moisture. The increased crude protein content was higher $(P<0.05)$ in SFM with $66 \%$ than $80 \%$ moisture content (w/w). Total increase in the level of crude protein was about $36 \%$ in this study (Tab. 2). The level of crude fibre was significantly $(P<0.05)$ reduced about $18 \%$ in total, and the fermentation effect on reduced crude fibre was higher in SFM with $66 \%$ than $80 \%$ water content (w/w). Phytic acid considered as ANF in monogastric animals were remarkably degraded about $37-42 \%$ irrespective to the moisture contents of SFM. ANFs were earlier shown to be remarkably degraded in SSF studies (Azza et al., 2013; Hassaan et al., 2018). Previous studies using Bacillus subtilis ATCC 6633, Bacillus amyloliquefaciens, Bacillus coagulans, Bacillus sp. AR-009 and Bacillus subtilis natto fermentations of various feed materials including SFM have reported a 3 to $104 \%$ increase of crude protein, a $17 \%$ reduction of crude fibre and a $80 \%$ increase of crude ash (Zhang et al., 2014). The same results regarding enrichment of nutrients and reduction of its phytic acid content were also reported with Bacillus subtilis fermentation of SBM (Teng et al., 2012; Dai et al., 2017; Yuan et al., 2017).

A recent study at our laboratory indicated that the same fermented SFM with ATCC PTA-6737 could not be fed more than $20 \%$ of the compound feed of young growing Carp (Cyprinus carpio) (Yigit et al., 2017). This results was in good agreement with other results reported elsewhere (Soltan et al., 2015; Hassaan et al., 2018; Jannathulla et al., 2018), where the SFM fermented with Bacillus subtilis can be fed to the fish and shrimps up to $25 \%$ and $5 \%$ of total diet, respectively.

According to the results fermenting SFM of high levels of moisture content (66 to $80 \%, \mathrm{w} / \mathrm{w}$ ) with Bacillus subtilis produced a feed material containing reduced phytic acid and crude fibre which was associated with protein, ash and protease enrichment. This new feed material 
can be used as alternative protein source or a functional feed material in farm animal nutrition.

Acknowledgements. The authors thank to Suleyman Demirel Universitesi Rektörlüğü, Bilimsel Araştırma Projeleri Birimi, Isparta, Turkey to provide a financial support to the study (Project no: 4469-YL2-15).

\section{REFERENCES}

1. Abusham A, Rahman RNZRA, Salleh AB, Basri M 2009. Optimization of physical factors affecting the production of thermo-stable organic solvent-tolerant protease from a newly isolated halo tolerant Bacillus subtilis strain Rand. Microbial Cell Factories, 8: 20 doi:10.1186/1475-2859-820.

2. Azza AM, Samia El-Safy F, Eman HFA (2013). Improvement of nutritional quality and antioxidant activities of fermented wastes by saccharomyces cervisiae, bacillus subtilis and pleurotus salmoneo-stramineus", Proceedings of 3rd Int. Conference on Biotechnology and its applications in Botany and Microbiology, April 17-18, 2013 Cairo, Egypt.

3. Afșin, M., 2010. Katı Faz Fermantasyon (Solid State Fermentation; SSF) Yöntemiyle Bacillus Licheniformis ATCC 14580'den Proteaz Üretimi. Dicle Üniversitesi Fen Bilimleri Enstitüsü, Biyoloji Anabilim Dalı, Yüksek Lisans Tezi, 79s, Diyarbakır.

4. AOAC (1990). Official Methods of Analysis. Association of Official Analytical Chemists. 15th Edition.

5. Barnes ME, Brown ML, Rosentrater KA, Sewell JR (2012). An initial investigation replacing fish meal with a commercial fermented soybean meal product in the diets of juvenile rainbow trout. Open Journal of Animal Sciences, 2(4), 234-243.

6. Baysal BE, Willett-Brozick JE, Badner JA, Corona W, Ferrel RE, Nimgaonkar VL, Detera-Wadleigh SD (2002). A mannosyltransferase gene at $11 \mathrm{q} 23$ is disrupted by a translocation breakpoint that co-segregates with bipolar affective disorder in a small family. Neurogenetics, 4: 4353.

7. Cai T, Chang KC, Lunde H (1996). Physicochemical properties and yields of sunflower protein enzymatic hydrolysates as affected by enzyme and defatted sunflower meal. Journol of Agriculture and Food Chemistry, 44: 3500-3506, DOI: 10.1021/jf9507396

8. Chantawannakul P, Oncharoen A, Klanbut K, Chukeatirote E, Lumyong S (2002). Characterization of proteases of Bacillus subtilis strain 38 isolated from traditionally fermented soybean in Northern Thailand. Science Asia, 28:241-245.

9. Chantet T,Sudarat T, Pornthap T (2011). Enhancing Protein Content in Soybean Meal by Mixed Culture Fermentation Process. KKU Science Journal, 40 (Supplement): 138-143.

10. Choubane S, Khelil O, Cheba BA (2015). Bacillus sp. R2 and Bacillus Cereus immobilized amylases for glucose syrup production. Procedia Technology, 19: 972-979, https:// doi.org/10.1016/j.protcy.2015.02.139.
11. Constantinscu AF, Petruta CC (2015). Biodiversity of Bacillus subtilis group and beneficial traits of Bacillus species useful in plant protection, Romanian Biotechnological Letters, 20:10737-10750.

12. Cotta MA, Hespell RB (1986). Proteolytic activity of the ruminal bacterium Butyrivibrio fibrisolvens. Applied and Environmental Microbiology, 8:51-52.

13. Dai CH, Ma R, He L, Huang S, Zhu Q, Ding LL (2017). Improvement of nutritional value and bioactivity of soybean meal by solid-state fermentation with Bacillus subtilis. LWT-Food Science Technology, 86: 1-7. https:// doi.org/10.1016/j.lwt.2017.07.041

14. EN ISO (2004). Standard No. 7932. Microbiology of food and animal feeding stuffs - Horizontal method for the enumeration of presumptive Bacillus cereus - Colonycount technique at $30^{\circ} \mathrm{C}$ ). European Committee for Standardization, Brussels.

15. Gessesse A, Mamo G (1999). High-level xylanase production by an alkaliphilic Bacillus sp. by using solidstate fermentation. Enzyme and Microbial Technology, 25:68-72.

16. Hassaan MS, Soltan MA, Mohammady EY, Elashry MA, ElHaroun ER, Davies SJ (2018). Growth and physiological responses of Nile tilapia, Oreochromis niloticus fed dietary fermented sunflower meal inoculated with Saccharomyces cerevisiae and Bacillus subtilis. Aquaculture, 495:592-601, https://doi.org/10.1016/j.aquaculture.2018.06.018

17. Haq IU, Mukhtar H (2004). Biosynthesis of proteases by Rhizopus oligosporus IHS13 in low-cost medium by solidstate fermentation, Journal of Basic Microbiology, 44 280-287.

18. Jannathulla R, Dayal JS, Ambasankar K, Muralidhar M (2018). Effect of Aspergillus niger fermented soybean meal and sunflower oil cake on growth, carcass composition and haemolymph indices in Penaeus vannamei Boone, 1931. 486: 1-8. Doı:10.1016/j.aquaculture. 2017.12.005.

19. Joseph I, Paul RR, Bhatnagar D (2008). Effect of solid state fermentation on nutrient composition of selected feed ingredients. Indian J. Fish., 55:327-332.

20. Karabulut A, Canbolat O (2005). Feed Evaluations and Analytical Methods. Uludağ University Agricultural Faculty Publication Office, Bursa, Turkey; 2005.

21. Karakoç DS (2006). Küflerden kati faz fermantasyon yöntemi ile lipaz üretimi. İstanbul Teknik Üniversitesi Fen Bilimleri Enstitüsü Gıda Mühendisliği Anabilim Dalı Yüksek Lisans Tezi, 70s, İstanbul.

22. Kiers JL, Meijer JC, Nout MJR, Rombouts FM, Nabuurs MJA, Meulen JVD (2003). Effect of fermented soya beans on diarrhoea and feed efficiency in weaned piglets. Journal of Applied Microbiology, 95:545-52. https://doi. org/10.1046/j.1365-2672.2003.02011.x

23. Kiers JL, Van laeken AEA, Rombouts FM, Nout MJR (2000). In vitro digestibility of Bacillus fermented soya bean. International Journal of Food Microbiology, 60: 163-169.

24. Kumar A, Duhan JS (2011). Production and characterization of amylase enzyme isolated from aspergillus niger mtcc104 employing solid state fermentation. International Journal of Pharma and Biosciences, 2:250-258. 
25. Mukherjee R, Chakraborty R, Dutta A (2016). Role of fermentation in improving nutritional quality of soybean meal - a review. Asian-Australasian Journal of Animal Sciences, 29: 1523-1529.

26. Mukherjee AK, Adhikari H, Sudhir KR (2008). Production of alkaline protease by a thermophilic bacillus subtilis under solid-state fermentation (SSF) condition using imperata cylindrica grass and potato peel as low-cost medium: characterization and application of enzyme in detergent formulation. Biochemical Engineering Journal, 39: 353-361.

27. Nair V (1990). Reduction of phytic acid content in canola meal by solid state fermentation. PhD thesis. The University of Ottaw, $146 \mathrm{pp}$.

28. Nutraferma, 2014. http://www.nutraferma.com/nf8. html, access date: 14.08.14.

29. Ohara Y, Yahata M (1996). L-Lactic acid production by Bacillus spp in anaerobic and aerobic culture. Journal of Fermentation and Bioengineering, 81:272-274

30. Özşölen F (2010). Katı faz fermentasyonu ile ligninolitik enzimlerin üretimi. Eskisehir Osmangazi Universitesi Fen Bilimleri Enstitüsü, Biyoloji Anabilim Dalı, 73s, Eskişehir.

31. Vig AP, Walia A (2001). Beneficial effects of rhizopus oligosporus fermentation on reduction of glucosinolates, fiber and phytic acid in rapeseed (brassica napus) meal. Bioresources Technology, 78:309-312.

32. Patel R, Dodia M, Singh SP (2005). Extracellular alkaline protease from a newly isolated haloalkalophilic bacillus sp.: production and optimization, process biochemistry , 40: 3569-3575.

33. Poulsen HD, Blaabjerg K (2017). Fermentation of rapeseed meal, sunflower meal and faba beans in combination with wheat bran increases solubility of protein and phosphorus. J Sci Food Agric.; 7:244-251. doi: 10.1002/ jsfa.7721.

34. Prakasham RS, Rao CS, Rao RS, Sarma PN (2007) Enhancement of acid amylase production by an isolated Aspergillus awamori. Journal of Applied Microbiology, 102: 204-211. https://doi.org/10.1111/j.13652672.2006.03058.x

35. Raheja RK, Kaur C, Singh A, Batia IS (1973). New colorimetric method for the quantitative of phospholipids without aid digestion. Journal of Lipid Research, 14:695.

36. Raimbault M (1998). General and microbiological aspects of solid substrate fermentation. Electronic Journal of Biotechnology, 1: 1-15.

37. Ravichandran S, Vimala R (2012). Solid state and submerged fermentation for the production of bioactive substances: a comparative study. International Journol of Science and Nature, 3:480-486.

38. Safari O, Farhangi MC, Carter B, Yakhchali S, Bai M, Sangatash M (2012). Study on the effect of solid state fermentation with aspergillus niger on antinutritional factors of canola protein concentrate with aim of using in the diet of rainbow trout (oncorhynchus mykiss). The Proceedings of the 1th International and the 4th National Congress on Recycling of Organic Waste in Agriculture, 26 - 27 April 2012 in Isfahan, Iran, pp:1-12.
39. Sangsoponjit S, Suphalucksana W, Srikijkasemwat $\mathrm{K}$ (2017). Effect of feeding sunflower meal on the performance and carcass characteristics of broiler chickens. Chemical Engineering Transactions Vol. 58, Doi: 10.3303/Cet1758141

40. Sarkar PK, Cook PE, Owens JD (1993) Bacillus fermentation of soybeans. World Journal of Microbiological Biotechnology, 9:295-299.

41. Shi C, Zhang Y, Lu Z, Wang Y (2017). Solid-state fermentation of corn-soybean meal mixed feed with Bacillus subtilis and Enterococcus faecium for degrading anti-nutritional factors and enhancing nutritional value; Journal of Animal Science and Biotechnology (2017) 8:50 DOI 10.1186/s40104-017-0184-2.

42. Singhaniaa R, Patel R, Carlos A, Soccol RK, Pandey A (2009). Recent advances in solid-state fermentation. Biochemical Engineering Journal, 44: 13-18.

43. Sneath PHA (1986). Section 13. Endospore-forming gram positive rods and cocci. In: Bergey's Manual of Systematic Bacteriology Vol 2, 9th ed (Edited by Sneath PHA, Mair NS, Sharpe ME and Holt JG), 1104-39. Williams \& Wilkins, Baltimore, MD

44. Soltan MA, Hassaan MS, Abdella MS, El-Syaad, GA, El-Ashry MA (2015). Yeast fermented sunflower meal as a replacer for fish meal in the diet of Nile tilapia, Oreochromis niloticus. Egypt. J. Aquat. Biol. \& Fish., 19: 65-72.

45. Teng D, Gao M, Yang Y, Liu B, Tian Z, Wang J (2012). Bio-modification of soybean meal with Bacillus subtilis or Aspergillus oryzae. Biocatalysis and Agricultural Biotechnology, 1:32-38. DOI: 10.1016/j. bcab.2011.08.005.

46. Uyar F, Baysal Z (2004). Production and optimization of process parameters for alkaline protease production by a newly isolated Bacillus $s p$. under solid state fermentation. Process Biochemistry, 39: 1893-1898. DOI: 10.1016/j. procbio.2003.09.016

47. Yamamoto M, Saleh F, Tahir M, Ohtsuka A, Hayashi K (2007). The Effect of koji-feed (fermented distillery by-product) on the growth performance and nutrient metabolizability in broiler. The Journal of Poultry Science, 44:291-296.

48. Yiğit NÖ, Bahadir KS (2017). Effects of Fermented Sunflower Meal with Bacillus subtilis on Growth Parameters, Digestibility and Body Composition in Carp (Cyprinus carpio), Limnofish. Ist International Symposium on Limnology and Freshwater Fisheries, 04 - 06 October 2017 in Egirdir-ISPARTA, Turkey.

49. Yonsel Ş (2010). Bacillus subtilis içeren küf ve bakterilere karşi koruyucu biyosidal ürün. 1. Ulusal Biyosidal Kongresi 4-7 Kasım, Antalya.

50. Yuan L, Chang J, Yin Q, Lu M, Di Y, Wang P, Wang Z, Wang E, Lu F (2017). Fermented soybean meal improves the growth performance, nutrient digestibility, and microbial flora in piglets. Animal Nutrition, 3:19-24. https://doi. org/10.1016/j.aninu.2016.11.003.

51. Zhang ST, Shi Y, Zhang S, Shang W, Gao X, Wang H (2014). Whole soybean as probiotic lactic acid bacteria carrier food in solid-state fermentation. Food Control 41:1-6. 